\title{
Transition from extension to subduction magmatism recorded by ignimbrites in central Oregon
}

HOLLI M. FREY ${ }^{\circ}$, REBECCA LIPPITT ${ }^{1}$, MATTHEW R. MANON $^{1}$, AND LAURA E. WATERS ${ }^{2}$

Union College, Schenectady, NY 12308, USA

(*correspondance: freyh@union.edu)

${ }_{2}$ New Mexico Tech, Socorro, NM 87801, USA

Multiple $<700 \mathrm{ka} 1-10 \mathrm{~km}^{3}$ explosive deposits are exposed east of the South Sister volcanic complex, centered around Bend, OR. These crystal-poor $(<10$ vol\%) andesites to rhyolites have been grouped into 5-6 pumice/tuff units based on location, physical appearance, chemistry, and stratigraphy/limited geochronology [1]. In this study, we investigate the bulk chemistry and calculated intrinsic variables of several units, including the Tumalo Tuff, Bend Pumice, Shevlin Park Tuff, and Columbia Canal Pumice. The older Tumalo Tuff/Bend Pumice (300-440 ka [1]) are rhyolites (69.6-74.1 wt\% $\mathrm{SiO}_{2}$ ), which differ significantly from the nearby $<50 \mathrm{ka}$ calc-alkaline South Sister rhyolites. The Tumalo/Bend deposits have a $\mathrm{Zr} / \mathrm{Sr}$ ratio of 1.5-5 and a $\mathrm{FeO} * / \mathrm{MgO}$ ratio of $6-20$, in contrast to the South Sister rhyolites, which have ratios $<1.5$ and $<6$. The Shevlin Park Tuff (175-225 ka [2]) and Columbia Canal Pumice are dacitic (63.8-67.6 wt\% $\mathrm{SiO}_{2}$ ), with similar major and trace element compositions compared to South Sister dacite lavas.

Two-oxide thermometry of [3] was used to calculate temperature and oxygen fugacity. Two samples of Shevlin Park Tuff featured a single population of oxide pairs, yielding average temperatures of $959 \pm 33^{\circ} \mathrm{C}$ and $934 \pm 33^{\circ} \mathrm{C}$, and $f \mathrm{O}_{2}$ of $0.25 \pm 0.10$ and $0.27 \pm 0.13 \Delta \mathrm{NNO}$, respectively. In contrast, Tumalo/Bend rhyolites have multiple oxide populations, including a common touching equlibrium pair which indicates cold and reducing conditions $\left(\sim 700^{\circ} \mathrm{C}\right.$ and $f \mathrm{O}_{2}$ of $\left.\leq-0.22 \pm 0.62 \Delta \mathrm{NNO}\right)$. In contrast, 17 samples of the young South Sister Devils Chain rhyolites yield Fe-Ti oxide temperatures $844 \pm 17$ to $868 \pm 16^{\circ} \mathrm{C}$ and $f \mathrm{O}_{2} \quad 0.7 \pm 0.1$ to $0.8 \pm 0.1 \Delta$ NNO. Thus, the Tumalo/Bend rhyolites differ significantly with respect to trace element composition, temperature, and oxygen fugacity compared to either the Shevlin Park or South Sister deposits, which exhibit arc-like characteristics. The Tumalo/Bend may be showing the effects of toroidal flow and reheating events during a period of transition from extension to subduction-driven magmatism that occurred between $\sim 300-200 \mathrm{ka}$.

[1] Hill (2008) OSU PhD dissertation. [2] Hildreth et al. (2012) USGS Map 3186. [3] Ghiorso and Evans (2008) AJS 308, 957-1039. 